\title{
Analysis on DNA Methylation in Chromolaena Odorata from Different Area and at Different Nitrogen Level by MSAP
}

\author{
C.Y.CHI, X.CHEN, D.D.GUO, G.H.DING* \\ Key Laboratory of Plant Biology in Colleges of Heilongjiang Province, Harbin, China \\ Life Science and Technology College of Harbin Normal University, Harbin, China \\ *Corresponding author
}

\begin{abstract}
Two species of Chromolaena odorata, with one indigenous in Mexico and the other introduced to Sipsongpanna, were cultivated by water culture method, and treated by high, normal and low nitrogen respectively, and the technology of methylation sensitive amplification polymorphism (MSAP) was used to explore the changes of DNA methylation polymorphism of the $C$. odorata with different sources and the influence of nitrogen nutrition levels on their DNA methylation polymorphisms. The study showed that DNA methylation levels and modes of the two species that undergone high nitrogen and low nitrogen treatments were changed, DNA methylation level of $C$. odorata invaded in Sipsongpanna was higher than that in the place of origin, and the higher the nitrogen supply level, the higher the DNA methylation.
\end{abstract}

KEYWORD: Chromolaena odorata; Mexico; Sipsongpanna; DNA methylation; MSAP

\section{INSTRUCTIONS}

DNA methylation is a modification process of transforming cytosine of CpG 5' dinucleotide into 5' methylcystein under the effect of methylation transferase (Zhang et al., 2010; Vanyushin and Ashapkin, 2011), it has been involved in a lot of basic research and application fields of life science, and is closely related to the regulation of gene expression, genomic imprinting, sex chromosome inactivation, cell differentiation, embryonic development and other biological processes(Gehring and Henikoff, 2007; Zilberman et al., 2007; Zilberman, 2008). DNA methylation has two main functions: a. defense, protecting genome being damaged by foreign insertion sequence and maintaining the stability of genome; $b$. regulator gene expression, playing an important regulatory role in cell development (Mandrioli, 2004; Meyer, 2011; Alba et al., 2012; Chang and Smith, 2012; Drenovsky et al., 2012).

Invasive plants refer to the species that are introduced by human activities, intentionally or unintentionally, from their native region to a new region, in environmental ecological system of which they form self-regeneration capacity, cause harm or impact on the surrounding ecosystems, industries, or human health, disrupting the ecological balance (Wan et al., 2009; Navajas et al., 2013; Parepa et al., 2013). They often have a strong ability to reproduce and spread, and the so-caused huge damage has become the global hot issue in the biological environment, safety and economy, and aroused great concern of all countries around the world. These species have caused serious economic losses to our country, with the most serious harm in the destruction of ecosystem and the loss of biodiversity, which will cause the loss of the rich, indigenous and peculiar biodiversity, and hard recovery (Drenovsky, et al., 2012). C. odorata has been recognized in the world as a kind of perennial invasive weed, originated in Central-South America and invaded to Asia and Africa in the middle period of the 19th century and then China in 1934, it has widely distributed in southern and other parts of China, with a continuous expansion trend (Ding and Blossey, 2009; Tang et al., 2011; Ramaswami and Sukumar, 2013; te Beest et al., 2013).

Explanation about invasion manners of the exotic plants has been given in some invasion mechanism hypothesis, such as enemy release hypothesis (Funk and Throop, 2010), novel weapon hypothesis (Bais, 2003; Levine et al., 2006), resource competition hypothesis (Eppstein and Molofsky, 2007), and nitrogen distribution evolutionary hypothesis (Feng et al., 2009), etc. There has been no report about the role of DNA methylation in exotic plant invasion. In this test, $C$. odorata, a typical invasive plant, was taken as the experimental object, the MSAP technology was used to explore the influence of DNA methylation polymorphism changes and nitrogen nutrition levels of the $C$. odorata with 
different sources on their DNA methylation polymorphisms, to reveal the correlation between DNA methylation and plant invasion and provide reference for enriching the plant invasion mechanism.

\section{MATERIALS AND METHODS}

Indoor seeding of the two species of $C$. odorata (respectively from Mexico and Sipsongpanna) was conducted in June 2011, illuminating for at 18 hours in $29^{\circ} \mathrm{C}$ illumination incubator and six hours in $25^{\circ} \mathrm{C}$ dark one. Hydroponics was adopted for the young plants and treated firstly by normal nitrogen treatment (nitrogen content of $210 \mathrm{mg} \cdot \mathrm{L}^{-2}$ ) with half the amount of Hoagland nutrient solution, and then by high nitrogen treatment (nitrogen content of 315 $\mathrm{mg} \cdot \mathrm{L}^{-2}$ ) with nitrogen content being increased to two-thirds of the original dose, and lastly by low nitrogen treatment (nitrogen content of $105 \mathrm{mg} \cdot \mathrm{L}^{-2}$ ) with nitrogen content being reduced to half of the original dose. Total nutrient solution concentration was controlled by the regularly measured conductance value.

MSAP analysis: refer to the methods of Xiong et al (Xiong et al., 1999)

Select clear stripes from PAGE gel, mark "with strip" by "1", "without stripe" by "0", and classify by "with or without strip" into three types of A, B and C: Hpa II and Msp I with stripes, i.e. none methylation or interior cytosine methylation, marked as $(1,1)$; Type B: Hpa II with stripes, Msp I without stripes, i.e. exterior cytosine methylation, marked as $(1,0)$; C type: $H p a$ II without stripes, $M s p$ I with strips, i.e. interior cytosine methylation, marked as $(0,1)$ (Ashikawa 2001).

\section{RESULTS}

\subsection{Comparison of DNA methylation levels between indigenous and invasive C. odorata}

DNA methylation of the $C$. odorata from two places are shown in Table 1. At "CCGG" of $C$. odorata indigenous in Mexico, the overall DNA methylation level was $21.17 \%$, among which the whole methylation point level was $9.49 \%$, and semi methylation point level of $11.68 \%$; while at "CCGG" of that introduced to Sipsongpanna, the overall DNA methylation level was $29.44 \%$, among which the whole methylation point level was $14.12 \%$, and semi methylation point level of $15.33 \%$. No matter for whole methylation and semi methylation, with regard to point level and the overall level of DNA methylation, the indigenous $C$. odorata was higher than the invasive one.

Table 1 DNA methylation levels in $C$. odorata from different area by MSAP analysis

\begin{tabular}{|c|c|c|c|c|c|}
\hline \multirow{2}{*}{ Locality of growth } & \multirow{2}{*}{ Total } & None-methylated sites & \multicolumn{3}{|c|}{ Methylated sites } \\
\cline { 4 - 6 } & & & Fully methylated sites & Semi- methylated sites & Total \\
\hline Mexico & 411 & 324 & $39(9.49 \%)$ & $48(11.68 \%)$ & $87(21.17 \%)$ \\
\hline Sipsongpanna & 411 & 289 & $58(14.12 \%)$ & $63(15.33 \%)$ & $121(29.44 \%)$ \\
\hline
\end{tabular}

\subsection{Effect of nitrogen nutrition level on DNA methylation of $C$. odorata}

DNA methylations obtained after treatment with different nitrogen levels are shown in Table 3. DNA methylations obtained after treatment with different nitrogen levels are shown in Table 2. At DNA "CCGG" of $C$. odorata, DNA methylation of both species after low nitrogen treatment was $19.23 \%$ on average, that after normal nitrogen treatment was $26.29 \%$, and high nitrogen treatment was $33.34 \%$. According to the data, the different nitrogen supply level will affect the degree of DNA methylation, for both the indigenous and invasive species, the higher the nitrogen supply level, the higher the DNA methylation.

Table 2 DNA methylation in C. odorata from two area at three nitrogen levels by MSAP

\begin{tabular}{|c|c|c|c|c|c|c|}
\hline \multirow{2}{*}{ Nitrogen level } & \multicolumn{2}{|c|}{ Methylated sites in C. odorata from Mexico } & \multicolumn{2}{c|}{ Methylated sites in C. odorata from Sipsongpanna } \\
\cline { 2 - 7 } & Fully methylated sites & Semi-methylated sites & Total & Fully methylated sites & Semi-methylated sites & Total \\
\hline Low nitrogen & $39(9.49 \%)$ & $27(6.57 \%)$ & $16.06 \%$ & $49(11.93 \%)$ & $43(10.47 \%)$ & $22.4 \%$ \\
\hline Normal nitrogen & $40(9.74)$ & $52(12.66 \%)$ & $22.4 \%$ & $58(14.12 \%)$ & $66(16.06 \%)$ & $30.18 \%$ \\
\hline High nitrogen & $61(14.85 \%)$ & $58(14.12 \%)$ & $28.96 \%$ & $76(18.50 \%)$ & $79(19.23 \%)$ & $37.73 \%$ \\
\hline
\end{tabular}




\subsection{Changing pattern of DNA methylation of $C$. odorata}

The DNA methylation patterns of the $C$. odorata. Demethylation at DNA "CCGG" of $C$. odorata with high nitrogen treatment accounted for $22.51 \%$, $35.89 \%$ lower than that with low nitrogen treatment; However, in terms of methylation enhancement, $C$. odorata with high nitrogen treatment was higher than that with low nitrogen treatment, $40.21 \%$ and $31.03 \%$, respectively; and the ratio of methylation patterns remaining unchanged at DNA "CCGG" were basically similar, $33.08 \%$ and $37.28 \%$, respectively. There have been the changes of DNA methylation pattern in the $C$. odorata with high or low nitrogen treatment and normal nitrogen treatment.

\section{DISCUSSION}

Until now, there is no research report about the relevant between plant invasion and DNA methylation. This study shows that the DNA methylation polymorphism are significantly differ among the two $C$. odorata from their origins respectively. The DNA methylation extent of $C$. odorata from Sipsongpanna is significantly higher than that from Mexico. Only from this point of view, gene expression of the $C$. odorata in the invaded area is suppressed by the increase of methylation. According to the analysis of influence of different nitrogen levels on DNA methylation of $C$. odorata, high nitrogen level led to higher level of methylation, and more genes could not be expressed; low nitrogen level led to lower methylation level, and more genes are expressed, which is called demethylation. Whether they were $C$. odorata from different origins or undergone treatment of different nitrogen supply levels, the circumstances of increased and decreased methylation have occurred. Previous studies showed that methylation happening within in the internal and adjacent regions of the genes could suppress the expression of these genes, and demethylation then could activate the expression (Zhang et al., 2010; Vanyushin and Ashapkin, 2011; Hernandez and Singleton, 2012). The successful invasion of the $C$. odorata, enhanced adaptability to the invaded area is a very important cause (Riis et al., 2010; Lankau, 2013; Monty et al., 2013). Epigenetic research showed that biological enhanced adaptability tends to be phenotype change rather than genotype change (Brock et al., 2005, Weinig et $a l$., 2007). Therefore, successful invasion of $C$. odorata may result from suppression of gene expression due to methylation, or expression of certain genes due to demethylation's suppression relief, or the joint action of both methylation and demethylation. In order to thoroughly reveal the role of methylation in plant invasion needs to be further identified genes which were methylated or demethylated.

In Liu Bao task group's MSAP analysis of the induced rice DNA methylation variance under low nitrogen level, it was demonstrated that significant decrease of rice DNA methylation happened when treated with low level of nitrogen and zero nitrogen, and the mode of decrease was mainly the lowering of CNG methylation level(Kou et al., 2011). Similar results were obtained in this study. In addition, the demethylation proportion of $C$. odorata treated with low nitrogen was higher than that treated with high nitrogen, but enhancement proportion of methylation was lower. Our speculation is that more nitrogen will mobilize more carbohydrates to synthetize protein after entering plants; however, the carbohydrates that enter into the secondary metabolism pathways to synthetize "new weapon" allelochemicals will be greatly reduced, thus more secondary metabolism-related genes are turned off, resulting in increase of DNA methylation and decrease of demethylation ratio. This inference will also be proved by another of our findings to be published (i.e. low nitrogen treatment makes the allelopathy effect of $C$. odorata more prominent).

\section{CONCLUSION}

DNA methylation levels and modes of the two species Chromolaena odorata that undergone high nitrogen and low nitrogen treatments were changed, DNA methylation level of $C$. odorata invaded in Sipsongpanna was higher than that in the place of origin, and the higher the nitrogen supply level, the higher the DNA methylation.

\section{ACKNOWLEDGEMENTS}

The paper was supported by Aid program for Science and Technology Innovative Research Team in Higher Educational Institutions of Heilongjiang Province and Harbin Normal University (KJTD2011-2) and Harbin Normal University Preparatory Program (the first session).

\section{REFERENCES}

[1] Alba, C., Bowers, M. D. \& Hufbauer, R. 2012. Combining optimal defense theory and the evolutionary dilemma model to refine predictions regarding plant invasion. Ecology 93(8): 1912-1921.

[2] Ashikawa, I. 2001. Surveying CpG methylation at 5'CCGG in the genomes of rice cultivars. Plant Mol Biol 45(1): 31-39.

[3] Bais, H. P., Vepachedu, R., Gilroy, S., Callaway, R. M. and Vivanco, J. M. 2003. Allelopathy and exotic plant 
invasion: from molecules and genes to species interactions. Science 301(5638): 1377-1380 DOI: 10.1126/science.1083245.

[4] Brock, M. T., Weinig, C. and Galen, C. 2005. A comparison of phenotypic plasticity in the native dandelion Taraxacum ceratophorum and its invasive congener T. officinale. New Phytol 166(1): 173-183 DOI: 10.1111/j.1469-8137.2004.01300.x.

[5] Chang, C. C. and Smith, M. D. 2012. Invasion of an intact plant community: the role of population versus community level diversity. Oecologia 168(4): 1091-1102 DOI: $10.1007 / \mathrm{s} 00442-011-2157-z$.

[6] Ding, J. and Blossey, B. 2009. Differences in preference and performance of the water lily leaf beetle, Galerucella nymphaeae populations on native and introduced aquatic plants. Environ Entomol 38(6): 1653-1660.

[7] Drenovsky, R. E., Grewell, B. J., D'Antonio, C. M., Funk, J. L., James, J. J., Molinari, N., Parker, I. M. and Richards, C. L. 2012. A functional trait perspective on plant invasion. Ann Bot 110(1): 141-153 DOI: 10.1093/aob/mcs100.

[8] Eppstein, M. J. and Molofsky, J. 2007. Invasiveness in plant communities with feedbacks. Ecol Lett 10(4): 253263 DOI: 10.1111/j.1461-0248.2007.01017.x.

[9] Feng, Y. L., Lei, Y. B., Wang, R. F., Callaway, R. M., Valiente-Banuet, A., Inderjit, Li, Y. P. and Zheng, Y. L. 2009. Evolutionary tradeoffs for nitrogen allocation to photosynthesis versus cell walls in an invasive plant. Proc Natl Acad Sci $U$ S A 106(6): 1853-1856 DOI: 10.1073/pnas.0808434106.

[10] Funk, J. L. and Throop, H. L. 2010. Enemy release and plant invasion: patterns of defensive traits and leaf damage in Hawaii. Oecologia 162(4): 815-823 DOI: 10.1007/s00442-009-1497-4.

[11] Gehring, M. and Henikoff, S. 2007. DNA methylation dynamics in plant genomes. Biochim Biophys Acta 1769(5-6): 276-286 DOI: 10.1016/j.bbaexp.2007.01.009.

[12] Hernandez, D. G. and Singleton, A. B. 2012. Using DNA methylation to understand biological consequences of genetic variability. Neurodegener Dis 9(2): 53-59 DOI: 10.1159/000333097.

[13] Kou, H. P., Li, Y., Song, X. X., Ou, X. F., Xing, S. C., Ma, J, Von Wettstein, D. and Liu, B. 2011. Heritable alteration in DNA methylation induced by nitrogendeficiency stress accompanies enhanced tolerance by progenies to the stress in rice (Oryza sativa L.). J Plant Physiol 168(14): 1685-1693 DOI: 10.1016/j.jplph.2011.03.017.

[14] Lankau, R. A. 2013. Species invasion alters local adaptation to soil communities in a native plant. Ecology 94(1): 32-40.

[15] Levine, J. M., Pachepsky, E., Kendall, B. E., Yelenik, S. G. and Lambers, J. H. 2006. Plant-soil feedbacks and invasive spread. Ecol Lett 9(9): 1005-1014 DOI: 10.1111/j.1461-0248.2006.00949.x.

[16] Mandrioli, M. 2004. Epigenetic tinkering and evolution: is there any continuity in the role of cytosine methylation from invertebrates to vertebrates? Cell Mol Life Sci 61(19-20): 2425-2427 DOI: 10.1007/s00018-004-4184-y.

[17] Meyer, P. 2011. DNA methylation systems and targets in plants. FEBS Lett 585(13): 2008-2015 DOI: 10.1016/j.febslet.2010.08.017.
[18] Monty, A., Bizoux, J. P., Escarre, J. and Mahy, G. 2013. Rapid plant invasion in distinct climates involves different sources of phenotypic variation. PLoS One 8(1): e55627 DOI: 10.1371/journal.pone.0055627.

[19] Navajas, M., Moraes, G. J., de Auger, P. and Migeon, A. 2013. Review of the invasion of Tetranychus evansi: biology, colonization pathways, potential expansion and prospects for biological control. Exp Appl Acarol 59(1-2): 43-65 DOI: 10.1007/s10493-012-9590-5.

[20] Parepa, M., Fischer, M. and Bossdorf, O. 2013. Environmental variability promotes plant invasion. Nat Commun 4: 1604 DOI: 10.1038/ncomms2632.

[21] Ramaswami, G. and Sukumar, R. 2013. Long-term environmental correlates of invasion by Lantana camara (Verbenaceae) in a seasonally dry tropical forest. PLoS One 8(10): e76995 DOI: 10.1371/journal.pone.0076995.

[22] Riis, T., Lambertini, C., Olesen, B., Clayton, J. S., Brix, H. and Sorrell, B. K. 2010. Invasion strategies in clonal aquatic plants: are phenotypic differences caused by phenotypic plasticity or local adaptation? Ann Bot 106(5): 813-822 DOI: 10.1093/aob/mcq176.

[23] Tang, S. C., Lu, S. H., Pan, Y. M., Wei, C. Q., Liu, M. C. and $\mathrm{Pu}, \mathrm{G}$. Z. 2011. [Control effects of mowing in combining with planting tree species on Chromolaena odorata in karst region of Guangxi, China]. Ying Yong Sheng Tai Xue Bao 22(7): 1944-1948.

[24] te Beest, M., Elschot, K., Olff, H. and Etienne, R. S. 2013. Invasion success in a marginal habitat: an experimental test of competitive ability and drought tolerance in Chromolaena odorata. PLoS One 8(8): e68274 DOI: 10.1371/journal.pone.0068274.

[25] Vanyushin, B. F. and Ashapkin, V. V. 2011. DNA methylation in higher plants: past, present and future. Biochim Biophys Acta 1809(8): 360-368 DOI: 10.1016/j.bbagrm.2011.04.006.

[26] Wan, F., Zhang, G., Liu, S., Luo, C., Chu, D., Zhang, Y., Zang, L., Jiu, M., Lu, Z., Cui, X., Zhang, L., Zhang, F., Zhang, Q., Liu, W., Liang, P. and Lei, Z. 2009. Invasive mechanism and management strategy of Bemisia tabaci (Gennadius) biotype B: progress report of 973 Program on invasive alien species in China. Sci_China C Life Sci 52(1): 88-95.

[27] Weinig, C., Brock, M. T., Dechaine, J. A. and Welch, S. M. 2007. Resolving the genetic basis of invasiveness and predicting invasions. Genetica 129(2): 205-216 DOI: 10.1007/s10709-006-9015-7.

[28] Xiong, L. Z., Xu, C. G., Saghai Maroof, M. A. and Zhang, Q.. 1999. Patterns of cytosine methylation in an elite rice hybrid and its parental lines, detected by a methylationsensitive amplification polymorphism technique. Mol Gen Genet 261(3): 439-446.

[29] Zhang, M., Kimatu, J. N., Xu, K. and Liu, B. 2010. DNA cytosine methylation in plant development. J Genet Genomics 37(1): 1-12 DOI: 10.1016/S1673-8527 (09) 60020-5.

[30] Zilberman, D. 2008. The evolving functions of DNA methylation. Curr Opin Plant Biol 11(5): 554-559 DOI: 10.1016/j.pbi.2008.07.004.

[31] Zilberman, D., Gehring, M., Tran, R. K., Ballinger, T. and Henikoff, S. 2007. Genome-wide analysis of Arabidopsis thaliana DNA methylation uncovers an interdependence between methylation and transcription. Nat Genet 39(1): 61-69 DOI: $10.1038 / n g 1929$. 